\title{
The Effects of Health Management System on the Growth of Chicken Small Farm in Southwest States of Nigeria
}

\author{
Jelili Olaide Saka ${ }^{1}$, Akinyele Oluwatomisin Kingsley Adesehinwa ${ }^{1}$, Ajoke Oyegbami ${ }^{1}$, Adeboye Joseph Omole ${ }^{1}$, \\ Gyoung-rae $\mathrm{Cho}^{2}$, Young-joo $\mathrm{Seol}^{2}$, Chongdae $\mathrm{Kim}^{3}$, Sung Woo Kim${ }^{4+}$ and Iksoo Jeon ${ }^{4^{+}}$ \\ ${ }^{1}$ Institute of Agricultural Research and Training, Obafemi Awolowo University, P.M.B. 5029, Moor Plantation, Ibadan, Nigeria \\ ${ }^{2}$ International Technology Cooperation Center, RDA, Jeonju 54875, Republic of Korea \\ ${ }^{3}$ Poultry Research Institute, National Institute of Animal Science, RDA, Pyungchang 25342, Republic of Korea \\ ${ }^{4}$ Animal Genetic Resources Research Center, National Institute of Animal Science, RDA, Namwon 55717, Republic of Korea
}

\begin{abstract}
Chicken production remains the foremost endeavor in the Nigerian livestock industry. However, disease incidence has been a major constraint on the growth of this subsector. This study assessed health management practices and disease incidence in smallholder chicken production enterprise in Southwest Nigeria using data from a farm survey of 240 farmers selected using a multistage sampling technique from 5 of 6 states in Southwest Nigeria. The study showed that vaccination was given by $96.8 \%$ of the famers, $97.8 \%$ dewormed their chickens, and $92.9 \%$ disinfected the coops against diseases. However, $37 \%$ of the farmers regularly consulted veterinarians, $25.7 \%$ consulted them during disease outbreaks, and $34.2 \%$ occasionally consulted veterinarians. Infectious bursal disease (IBD), coccidiosis, and chronic respiratory disease (CRD) were the major diseases reported by $17.1 \%, 12.9 \%$, and $7.1 \%$ of the farmers, respectively. Mortality rate was $37.8 \%$, although this varied with disease. However, there was a growth of $157.4 \%$ in stock size between the establishment of the farms and the survey period.

(Key words: health management system, smallholder chicken production, Southwest Nigeria)
\end{abstract}

\section{INTRODUCTION}

The livestock sub-sectors of Nigeria has shown increasing potential in accelerating achievement of food security, selfsufficiency, increased incomes and quality of rural life (Okumadewa 1999, Diao et al., 2009). In the livestock industry, Aromolaran et al. (2009) reported that the development of poultry industry would be the fastest means of preventing the protein deficiency which prevails in most of the developing countries. In Nigeria, the poultry sub-sector of local livestock industry has exhibited tremendous growth in recent years. However, Diao et al. (2009) also reported that the growth rate of the sub sector from 2000 and 2005 was 5.9\% per year until the growth was truncated by the incidence of HPAI in 2006. Earlier estimates (Ojo, 2003) showed that the contribution of poultry production (meat and eggs) to total livestock output increased from $26 \%$ in 1995 to $27 \%$ in 1999 with an increase in egg production alone accounting for about $13 \%$ during the period. However, a prominent feature of this growth in poultry sub-sector is the increase in number of small and medium scale poultry farms which dominates rearing of chicken. In poultry production, smallholder represents one of few opportunities for savings, investment and security against risks and accounts for approximately $90 \%$ of total poultry production in Nigeria (Branckaert, 1999). These categories of farms include backyard poultry farms, neighborhood farms in urban and peri-urban communities particularly in the southern part of the country.

One of the major challenges in livestock production of Nigeria is incidence of diseases in poultry sub-sector in which viral diseases of virulent potential remain. According to Fadiga et al. (2013), the occurrence of endemic animal diseases, followed by poor animal nutrition, stands above all other factors in contribution towards poor productivity of livestock sector. So, the incidence of diseases has remained a major threat in poultry industry in Nigeria with manifesting loss in terms of low productivity of meat and egg, morbidity and mortality (Fadiga et al., 2013; Akintunde and Adeoti, 2014). The threat of diseases is believed to be more severe in smallholder dominated agriculture. This is usually attributed to the characte-

\footnotetext{
* Corresponding Authors: Sung Woo Kim, Ph.D. and Ik Soo Jeon, Ph. D.

† To whom correspondence should be addressed : sungwoo@korea.kr and jeonis@korea.kr
} 
ristic low level of investment due to poor access to credit resulting in low level of use of modern inputs and technologies. Sheahan and Barret (2014) view this as a conventional belief which holds that Sub-Saharan African farmers hardly use new modern inputs despite the fact that most growth-inducing and poverty-reducing agricultural growth in the region is expected to come largely from expanded use of inputs that embody improved technologies, particularly improved seed, fertilizers and other agro-chemicals, machinery, and irrigation. Such conception, if upheld in the livestock sector could undermine access of farmers to veterinary resources, could consequently limit the health and disease management potential of the farmers thereby resulting in low productivity. However, there have been several programs and initiatives both home grown and under different global partnership targeted at achieving sustainable growth in the agricultural subsector of the economy of countries in Sub-Sahara Africa. In Nigeria, the Agricultural Transformation Agenda of the last regime had improved access to modern inputs on its primary focus. The poultry sub sector benefited the supply of foundation stocks, feeds and drugs mostly to smallholder farmers nationally. Therefore, it is necessary to examine the extent to which such and similar initiatives has improved smallholder's poultry production with specific focus on disease management practices adopted by the farmers, diseases incidence, associated mortality and the impacts on growth of the chicken industry.

\section{MATERIALS AND METHODS}

\section{Study Area and Climate}

The study was carried out in the Southwestern agro-ecological zone on Nigeria with 3 type of chicken including layers, broilers and cockerels. The agro-ecological zone is located between latitude $6^{\circ} \mathrm{N}$ and $4^{\circ} \mathrm{S}$ and longitude $4^{\circ} \mathrm{W}$ and $6^{\circ} \mathrm{E}$. The land area contains $114,271 \mathrm{~km}^{2}$ representing $12 \%$ of the country's land mass and comprises of 6 States namely Ekiti, Lagos, Ogun, Ondo, Osun and Oyo States. This zone was characterized by a typically equatorial climate with distinct dry and wet seasons with the main growing season lasting up to 9 months with two peaks in July and September. Rainfall ranges between 2,600 $\mathrm{mm}$ in the coastal areas of Lagos and Ogun States to nearly 1,200 $\mathrm{mm}$ in the northern areas of Ondo,
Oyo and Osun States. Average rainfall is $1,480 \mathrm{~mm}$ with a mean monthly temperature range of $18 \sim 24^{\circ} \mathrm{C}$ during the raining season and $30 \sim 35^{\circ} \mathrm{C}$ during the dry season. The zone also has four distinct sub-ecologies comprising of swamp mangrove forest, moist and dry lowland forest, woodland forest and savanna mosaic and the soil has low to medium productivity potential. Major food crops grown include cassava, maize, yam, cowpea, sorghum, millet, while the tree crops include cocoa, coffee, kolanut, oil palm, and cashew. The region is also noted for production of livestock species including goat, sheep, cattle, pig and poultry. The zones have the largest concentration of commercial poultry farms largely dominated by chicken raised for both meat and egg.

\section{Data Collection}

Data were collected through a farm survey of 250 small and medium scale chicken farmers selected from 5 out of the 6 states that make up the Southwest agro-ecological zones namely Ekiti, Lagos, Ogun, Ondo, and Oyo by multi-stage sampling technique of questionnaires. Smallholder farmers were categorized by stock size of $20 \sim 1,000$ chicken on their facility. The categorization was based on information obtained during the pre-survey meeting with poultry farmers and extension agents in the selected areas. The information essentially was based on the cost of feeding birds in determining the size of birds that households would ordinarily keep for household food security and commercial purposes. Consequently a threshold of $20 \sim 1,000$ was established as the lower and upper limit for smallholder farmers. Subsequently, 50 farmers classified under this category were purposively selected in each of the state for interview with the support of the Extension and Livestock Department of the Agricultural Development Programs (ADPs) of the local states. Two zones prominent for poultry reproduction were selected in each of the state with 25 farmers which were selected randomly from the list of small farmers obtained from the ADP Office of local states. However, 240 of the questionnaires certified as containing adequate information were used for the analysis.

Using structured questionnaire, data were collected on the demographic characteristics of the farmers with a view of describing the population of smallholder chicken farmers in the region. Information were collected on production practices 
adopted by farmers, type of breeds of chicken reared and sources of stock, stock size and composition, management and housing systems adopted, feed and feeding, access to veterinary services, disease incidence and level of severity.

\section{Data Analyses}

Data were analyzed by Fisher's exact test such as frequency distribution, mean and percentages while the growth potential of smallholder chicken production was determined by comparing initial stock size with present stock size. Owing to the inability of the survey to get reliable cost estimates of production practices from the farmers due to poor record keeping, farmers perception was used to assess the profitability while the growth potential was estimated based on comparison between stock size at inception of the farm and stock size at the period of the survey.

\section{RESULTS AND DISCUSSION}

\section{Management Systems Adopted by Farmers}

The distribution of chicken farmer's choice of management and housing systems is shown in Table 1 . The chicken were prominently reared by the farmers under intensive management system (87.8\%) while $7.7 \%$ and $4.5 \%$ adopted semi-intensive and extensive system respectively. Under the intensive systems, birds were prominently kept in deep litter system (48.6\%) and battery cages $(44.6 \%)$. A few of the farmers also reared their birds in movable wooden boxes $(2.8 \%)$ and woven hutches (4.0\%) respectively. Poultry pens are usually made of concrete floor with wooden walls covered with wire nets either for battery cage or deep litter system. In some cases, pens are concrete or cement block buildings to rear the bird especially for homestead or backyard poultry farms.

\section{Feeds and Feeding}

The quality of feed and appropriateness of feeding regime are crucial to animal performance and their cost accounts for major part of production. The distribution of feed type and feeding choice by chicken farmers were summarized in Table 2. The majority of the farmers $(95.4 \%)$ were feeding their birds with compounded feed while birds were fed twice (74.8 $\%)$ or three times $(24.8 \%)$ per day. In feeding birds twice daily, $52.9 \%$ of the farmers fed their birds in the morning and evening while $20 \%$ fed birds in the morning and afternoon. However, $26.7 \%$ of the farmers feed birds in the morning, afternoon and evening (three times a day).

Birds were served water silmultaneously with feed by 58.1 $\%$ of the farmers, $24.2 \%$ served the birds with water after feed, $7.4 \%$ before feed while $10.2 \%$ serveed water rountinely in the morning. The prominence of the use of compounded

Table 1. Management pattern and housing systems used by farmers for chicken production

\begin{tabular}{|c|c|c|c|c|c|c|}
\hline \multirow{2}{*}{ Management system } & \multicolumn{5}{|c|}{ Name of local states $(\%)$} & \multirow{2}{*}{ Total } \\
\hline & Ekiti & Lagos & Ogun & Ondo & Oyo & \\
\hline Intensive & $43(97.7)$ & $40(95.2)$ & $32(76.2)$ & $38(86.4)$ & $41(83.7)$ & $194(87.8)$ \\
\hline Semi intensive & & $2(4.8)$ & $8(19.1)$ & $4(9.1)$ & $3(6.1)$ & $17(7.7)$ \\
\hline Extensive & $1(2.3)$ & & $2(4.8)$ & $2(4.6)$ & $5(10.2)$ & $10(4.5)$ \\
\hline \multicolumn{7}{|l|}{ Housing system } \\
\hline Deep litter system & $24(65.6)$ & $9(32.1)$ & $15(33.5)$ & $20(55.6)$ & $18(46.2)$ & $86(48.6)$ \\
\hline Battery cage & $10(28.6)$ & $19(67.9)$ & $22(56.4)$ & $12(33.3)$ & $16(41.0)$ & 79 (44.6) \\
\hline Wooden boxes & $1(2.9)$ & & $2(5.1)$ & $1(2.8)$ & $1(2.6)$ & $5(2.8)$ \\
\hline Woven hutches & & & & $3(8.3)$ & $4(10.3)$ & $7(4.0)$ \\
\hline
\end{tabular}

In the manage system, "intensive" means that chicken was raised fully in confined house or cages. Also "Semi intensive" is that chicken are confined to a certain area with access to shelter. The "extensive" infers under free-rage or scavenging conditions or may having rudimentary shelters. In housing system, "deep litter system" use fully confined with floor space allowance of 3 to 4 birds $/ \mathrm{m}^{2}$ within a house, but can move around freely. The "battery cage" adopted by commercial egg layer industry means that chicken were kept through out their life in cages. 
Table 2. Distribution of feed type and feeding choice in chicken farms

\begin{tabular}{|c|c|c|c|c|c|c|}
\hline \multirow{2}{*}{ Feed type } & \multicolumn{5}{|c|}{ Name of local states $(\%)$} & \multirow{2}{*}{ Total } \\
\hline & Ekiti & Lagos & Ogun & Ondo & Oyo & \\
\hline Whole grains & & & & $1(2.0)$ & & $1(0.4)$ \\
\hline Compounded feed & $44(97.9)$ & $48(100.0)$ & $41(91.1)$ & $46(92.0)$ & $48(96.0)$ & $229(95.4)$ \\
\hline Spent grain & $1(2.1)$ & & $1(2.2)$ & $2(4.0)$ & $1(2.0)$ & $5(2.1)$ \\
\hline Compounded ration/spent grain & & & & $1(2.0)$ & $1(2.0)$ & $2(0.8)$ \\
\hline Compounded ration/kitchen waste/spent grain & & & $3(6.7)$ & & & $3(1.3)$ \\
\hline \multicolumn{7}{|l|}{ Number of feeding regimes } \\
\hline Once & & & & $1(2.0)$ & & $1(0.4)$ \\
\hline Twice & $34(75.6)$ & 45 ( 93.8) & $37(82.2)$ & $30(60.0)$ & $32(64.0)$ & $178(74.8)$ \\
\hline Thrice & $11(24.4)$ & $3(6.2)$ & $8(17.8)$ & $19(38.0)$ & $18(36.0)$ & $59(24.8)$ \\
\hline \multicolumn{7}{|l|}{ Period of feeding } \\
\hline Morning & & & & $1(2.0)$ & & $1(0.4)$ \\
\hline Morning/afternoon & $5(10.6)$ & $6(12.5)$ & $13(28.9)$ & $7(14.0)$ & $17(34.0)$ & $48(20.0)$ \\
\hline Morning/evening & $28(59.6)$ & $39(81.3)$ & $24(53.3)$ & $22(44.0)$ & $14(28.0)$ & $127(52.9)$ \\
\hline Morning/afternoon/evening & $14(29.8)$ & $3(6.3)$ & $8(17.8)$ & $20(40.0)$ & $19(38.0)$ & $64(26.7)$ \\
\hline \multicolumn{7}{|l|}{ Period for serving chicken with water } \\
\hline Before feeding & $3(7.7)$ & $6(15.4)$ & $2(5.1)$ & $3(6.3)$ & $2(5.1)$ & $16(7.4)$ \\
\hline After feed & $4(10.3)$ & $11(26.2)$ & $12(30.0)$ & $10(20.8)$ & $15(30.0)$ & $52(24.2)$ \\
\hline Together with feed & $27(69.2)$ & $21(53.9)$ & $23(59.0)$ & $27(56.3)$ & $27(54.0)$ & $125(58.1)$ \\
\hline Routinely in the morning & $5(12.8)$ & $1(2.6)$ & $2(5.1)$ & $8(16.7)$ & $6(12.0)$ & $22(10.2)$ \\
\hline
\end{tabular}

ration among the farmers is indicative of the importance that the farmers attached to use of quality feed for enhanced productivity. However, its attendant challenges is the high cost of compounded feed traceable to the increase in market price of the feed ingredients.

In recent times, research attention has shifted to the formulation of cost effective feeds using locally available materials that have been hitherto treated as wastes or completely neglected. In addition to being of nutritional importance, some of these materials have also been found to have antibiotic properties. These efforts have yielded locally formulated costeffective feed targeted at reducing the high cost of feeding and improving productivity of chicken. However, achieving the desired end result depends on substantial adoption of these technologies by the farmers.
The result in Table 3 shows low level of awareness ranging from $20.8 \%$ to $24.6 \%$ among the farmers. Consequently, the level of sustained adoption was very low with a range of $5.0 \%, 11.3 \%$ and $7.9 \%$ for $30 \%$ replacement of maize with palm kernel meal supplemented with enzyme in broiler feed, enzyme treatment of corn bran for partial replacement of maize in broiler feed and the use of moringa leaf meal as antibiotic in broiler production.

These results points to the need for intensified efforts on the promotion of the technologies. There is also the need for further investigation of the reasons for the abandonment of these technologies among few of the farmers that once adopted. However, it suffice to mention that the level of adoption of improved management practices such as use of compounded feed, vaccination, disinfection of chicken pens and other 
Table 3. Status of new feeding types used by small farmer for broiler production

\begin{tabular}{|c|c|c|c|c|c|c|}
\hline \multirow{2}{*}{ Feeding type } & \multicolumn{5}{|c|}{ Name of local states $(\%)$} & \multirow{2}{*}{ Total } \\
\hline & Ekiti & Lagos & Ogun & Ondo & Oyo & \\
\hline \multicolumn{7}{|c|}{ Use of moringa leaf meal as antibiotics in broiler production } \\
\hline Not aware & $29(61.7)$ & $39(81.3)$ & $30(66.7)$ & $34(68.0)$ & $32(66.7)$ & $164(68.3)$ \\
\hline Aware & $16(34.0)$ & 7 (14.6) & $11(24.4)$ & $9(18.0)$ & $16(33.3)$ & $59(24.6)$ \\
\hline Not adopted & $37(78.7)$ & $42(87.5)$ & $35(77.8)$ & $38(76.0)$ & $38(79.2)$ & $190(79.2)$ \\
\hline Abandoned & $4(8.5)$ & $4(8.3)$ & - & $2(4.0)$ & $4(8.3)$ & $14(5.8)$ \\
\hline Adopted & $4(8.5)$ & - & $6(13.3)$ & $3(6.0)$ & $6(12.5)$ & $19(7.9)$ \\
\hline \multicolumn{7}{|c|}{ Enzyme + corn bran as partial replacement for maize in broiler feed } \\
\hline Not aware & $32(68.1)$ & $33(68.8)$ & $31(68.9)$ & $31(62.0)$ & $30(62.5)$ & $157(65.4)$ \\
\hline Aware & $10(21.3)$ & $12(25.0)$ & $10(22.2)$ & $9(18.0)$ & $14(29.2)$ & $54(22.5)$ \\
\hline Not adopted & $36(76.6)$ & $33(68.8)$ & $34(75.6)$ & $36(72.0)$ & $36(75.0)$ & $174(72.5)$ \\
\hline Abandoned & - & $2(4.2)$ & $3(6.7)$ & $2(4.0)$ & $3(6.3)$ & $10(4.2)$ \\
\hline Adopted & $6(12.8)$ & $10(20.8)$ & $4(8.9)$ & $2(4.0)$ & $5(10.4)$ & $27(11.3)$ \\
\hline \multicolumn{7}{|c|}{$10 \%$ replacement of maize with palm kernel meal in broiler feed } \\
\hline Not aware & $28(59.6)$ & $33(68.8)$ & $22(48.9)$ & $28(56.0)$ & $24(12.0)$ & $136(56.7)$ \\
\hline Aware & $13(27.7)$ & $9(18.8)$ & $18(40.0)$ & $13(26.0)$ & $23(47.9)$ & $76(31.7)$ \\
\hline Not adopted & $20(42.6)$ & 31 (64.6) & $32(71.1)$ & $33(66.0)$ & $30(62.5)$ & $165(68.8)$ \\
\hline Abandoned & $1(2.1)$ & $6(12.5)$ & $3(6.7)$ & $5(10.0)$ & $6(12.5)$ & $21(8.8)$ \\
\hline Adopted & $20(42.6)$ & $5(10.4)$ & $5(11.1)$ & $3(6.0)$ & $11(22.9)$ & $26(10.8)$ \\
\hline \multicolumn{7}{|c|}{$30 \%$ replacement of maize with palm kernel supplemented with enzyme in broiler feed } \\
\hline Not Aware & $30(63.8)$ & $35(72.9)$ & $26(57.8)$ & $32(64.0)$ & $39(81.3)$ & $162(67.5)$ \\
\hline Aware & $8(17.0)$ & $3(6.3)$ & 7 (15.6) & $13(26.0)$ & 19 (39.6) & $50(20.8)$ \\
\hline Not Adopted & $20(42.6)$ & $28(58.3)$ & $18(40.0)$ & $17(34.0)$ & $19(39.6)$ & $102(42.5)$ \\
\hline Abandoned & $2(4.3)$ & $4(8.3)$ & $1(2.2)$ & $2(4.0)$ & $1(2.1)$ & $10(4.2)$ \\
\hline Adopted & $1(2.1)$ & $1(2.1)$ & $6(13.3)$ & $1(2.0)$ & $3(6.3)$ & $12(5.0)$ \\
\hline
\end{tabular}

good management practices were high among the farmers.

\section{Veterinary and Health Management Practices}

The outbreak of pest and notorious diseases have been a major limiting constraint on expansion of poultry industry. The country has recorded cases of avian influenza among others in recent times. The losses attributed to the disease has led to intensified campaing on Good Management Practices in the poultry industry. The interventions emphasized routine hygines, regular vacination against poultry diseases and use of appropriate medications among others.

The results in Table 4 shows that $37 \%$ percent of the farmers had regular schedule for veterinary consultancy services for their farm while $25.7 \%$ and $34.2 \%$ invite veterinary care providers only when there are signs of diseases andoccasionally. However, $96.8 \%$ of the farmers vacinate their birds against notable diseases, $97.8 \%$ also deworm their birds while $(92.9 \%)$ disinfect their pens using different brands of disinfectants. It was also observed during the survey that some of the farmers do carry out some veterinary self-cares on their 
Table 4. Veterinary care system conducted by chicken farmers across states

\begin{tabular}{|c|c|c|c|c|c|c|}
\hline \multirow{2}{*}{ Veterinary services } & \multicolumn{5}{|c|}{ Name of local states $(\%)$} & \multirow{2}{*}{ Total } \\
\hline & Ekiti & Lagos & Ogun & Ondo & Oyo & \\
\hline At disease symptom & $6(14.3)$ & $24(53.3)$ & $6(14.6)$ & $14(31.8)$ & $7(14.0)$ & $57(25.7)$ \\
\hline Occasionally & $3(7.1)$ & $20(44.4)$ & $24(58.5)$ & $19(43.2)$ & $10(20.0)$ & $76(34.2)$ \\
\hline Routinely & $32(76.2)$ & $1(2.2)$ & $11(26.8)$ & $9(20.5)$ & $31(20.5)$ & $84(37.8)$ \\
\hline \multicolumn{7}{|l|}{ Vaccination } \\
\hline Done & $45(97.8)$ & $46(100.0)$ & $39(95.1)$ & $44(89.8)$ & $50(100.0)$ & $224(96.8)$ \\
\hline Not done & $1(2.2)$ & & $2(4.8)$ & $5(10.2)$ & & $8(3.4)$ \\
\hline \multicolumn{7}{|l|}{ Deworming } \\
\hline Done & $43(97.7)$ & $45(100.0)$ & $40(100.0)$ & $45(95.7)$ & $48(96.2)$ & $221(97.8)$ \\
\hline Not done & $1(2.3)$ & & & $2(4.3)$ & $2(3.8)$ & $5(2.2)$ \\
\hline \multicolumn{7}{|l|}{ Disinfection } \\
\hline Done & $43(91.5)$ & $46(95.8)$ & $41(93.4)$ & $45(90.0)$ & $48(92.3)$ & $223(92.9)$ \\
\hline Not done & $4(8.5)$ & $2(4.2)$ & $2(4.7)$ & $5(10.0)$ & $4(7.7)$ & $17(7.1)$ \\
\hline
\end{tabular}

birds (e.g. vacination), having techniques through previous trainings or interactions with service providers.

Despite the various measures were taken by the farmers in disease management, the incidence of diseases remained one of the challenges that the farmers have to cope with. The results in Table 5 shows that $59.7 \%$ of the farmers recorded incidence of diseases on their farm in the last one year while 40.3 did not. The distribution also shows that greater percentages of farmers in Ekiti (86.1\%), Ondo (70\%) and Ogun (55
$\%)$ recorded the incidence of diseases on their farm as against $47.8 \%$ and $40.4 \%$ of the farmers in Lagos and Oyo States respectively.

The prominent diseases recorded by the farmers include IBD (17.1\%) and coccidiosis (12.9\%) in southwest states of Nigeria. Chronic respiratory disorder (CRD) (7.1\%), Newcastle $(6.7 \%)$ and fowlpox (4.6\%) were also recorded but less prevalent among the farms. Average number of birds infected by the disease was estimated at 230 birds resulting in mor-

Table 5. Distribution of diseaseas incedence on chicken farm across states

\begin{tabular}{|c|c|c|c|c|c|c|}
\hline \multirow{2}{*}{ Disease incidence } & \multicolumn{5}{|c|}{ Name of local states $(\%)$} & \multirow{2}{*}{ Total } \\
\hline & Ekiti & Lagos & Ogun & Ondo & Oyo & \\
\hline Not recorded & $6(14.0)$ & $24(52.2)$ & $18(45.0)$ & $15(30.0)$ & $28(59.6)$ & $91(40.3)$ \\
\hline Recorded & $37(86.1)$ & $22(47.8)$ & $22(55.0)$ & $35(70.0)$ & $19(40.4)$ & $135(59.7)$ \\
\hline \multicolumn{7}{|l|}{ Notable diseases } \\
\hline IBD (Gumboro) & $13(27.7)$ & $4 \quad(8.3)$ & 7 (15.6) & $11(22.0)$ & $6(12.5)$ & 41 (17.1) \\
\hline Coccidiosis & $11(23.4)$ & 7 (14.6) & $4(8.9)$ & $5(10.0)$ & $4(8.3)$ & 31 (12.9) \\
\hline CRD & $4(8.5)$ & $3(6.3)$ & $1(2.2)$ & $5(10.0)$ & $4(8.3)$ & $17(7.1)$ \\
\hline Fowl pox & $3(6.4)$ & $1(2.1)$ & $1(2.2)$ & $4(8.0)$ & $2(4.2)$ & $11(4.6)$ \\
\hline Newcastle & $4(8.5)$ & $4(8.3)$ & $3(6.7)$ & $3(6.0)$ & $2(4.2)$ & $16(6.7)$ \\
\hline
\end{tabular}

CRD: Chronic respiratory disorder, IBD; Infectious bursal disease. 
tality of average number of 87 birds representing $37.8 \%$ mortality due to disease incidence (Table 6). However, the motalities of diseses could be varied highly between $8.6 \sim 53.8 \%$ by the nature of causatives.

\section{Initial and Present Stock Size}

The growth of poultry industry in west-south Nigeria was summarized in Table 7 and Table 8 within an average interval of 10.7 years. The average stock size of layer birds at the initial stage was 226 but the rearing capacity of the farmers has grown significantly to an average stock size of 450 layer birds at present $(p<0.05)$. However, there is no significant difference in the average initial stock size of broilers and cockerels on the farm $(p>0.05)$. The results in Table 8 also show the growth of chicken stock sizes in types across local states of Nigeria. Lagos state had the largest average stock size for layers, while the average stock size of broilers and cockerels of Ekiti state was significantly higher than those of other states respectively $(p<0.05)$. However, the total initial stock size of all type of birds in Lagos State (855) was significantly greater than the initial stock size of birds in Ekiti (487), Ogun (330), Ondo (259) and Oyo (310) States respectively $(p<0.05)$. The stock size of all categories of birds at present in Ekiti State $(1,195)$ is greater that the stock size at present in Lagos $(834)$, Ogun (324), Ondo (585) and Oyo (880) $(p<0.05)$. The total initial stock size of local states was 481 while the average total stock size at the period of the survey was 792 . Average

Table 6. The mortality of chicken disease in south-west states of Nigeria

\begin{tabular}{cccc}
\hline \hline Major diseases & $\begin{array}{c}\text { Number } \\
\text { of infected } \\
\text { chicken }\end{array}$ & $\begin{array}{c}\text { Number } \\
\text { of lost } \\
\text { chicken }\end{array}$ & $\begin{array}{c}\text { Mortality } \\
(\%)\end{array}$ \\
\hline Coccidiosis & 257 & 22 & 8.6 \\
CRD & 104 & 56 & 53.8 \\
IBD (Gumboro) & 341 & 134 & 39.3 \\
Newcastle & 76 & 21 & 27.6 \\
Fowl pox & 218 & 112 & 51.4 \\
\hline Average number of & 230 & 87 & 37.8 \\
5 major diseases & & & \\
\hline
\end{tabular}

CRD: Chronic respiratory disorder, IBD; Infectious bursal disease.
Table 7. Average initial and present stock sizes among types of chicken

\begin{tabular}{cccc}
\hline $\begin{array}{c}\text { Type of } \\
\text { chicken }\end{array}$ & $\begin{array}{c}\text { Initial stock size } \\
\text { (SD) }\end{array}$ & $\begin{array}{c}\text { Present stock size } \\
(\mathrm{SD})\end{array}$ & $F$-value \\
\hline Layers & $226.70(420.95)$ & $449.92(869.51)$ & $3.57^{* *}$ \\
Broilers & $104.00(17.38)$ & $157.23(24.64)$ & 1.76 \\
Cockerels & $104.00(17.41)$ & $158.15(27.49)$ & 1.66 \\
\hline
\end{tabular}

The initial stock size was the number of starting birds the farm was first established.

The present stock size was the number of birds at the time of survey in 2016.

** $F$-value with superscript was significantly different within columns $(p<0.01)$.

growth rate between initial stock size on establishment of farm and during period of the survey was estimated as 164.7 $\%$, although the mean values varied significantly across states with Ogun State having the least growth rate of $25.04 \%$ while the highest was recorded in Ondo state $261.85 \%$.

\section{CONCLUSION}

The low level of investment is evident in the condition of the housing of some of the farms visited especially among farmers who operate their chicken enterprise as backyard farms. However, the impact of their access to technical information, training and development of the industry is exhibited in the wide reliance on registered commercial hatcheries for quality foundation stock, use of compounded feeds, vaccination of birds against diseases, deworming and disinfecting of poultry pen to prevent diseases and their use of water from safe sources. Despite these, incidences of diseases were recorded by some of the farms with average mortality rate of 37.8 $\%$ which is considerably high. Although IBD and coccidiosis were the two prominent diseases recorded by the farmers, greater mortality were recorded due to $\mathrm{CRD}$, fowl pox and IBD. However, the incidence of these diseases were not enough to have led to significant disinvestment in chicken production by the smallholder farmers as enormous growth rate was recorded although the growth rate differs across state and categories of bird reared. This suggests an attractiveness of the enterprise for further investment. Effective implemen- 
Table 8. Stock size difference at initial and present number of chicken across states

\begin{tabular}{|c|c|c|c|c|c|c|c|c|}
\hline \multirow{2}{*}{$\begin{array}{l}\text { Type of } \\
\text { chicken }\end{array}$} & \multirow{2}{*}{$\begin{array}{l}\text { Stock } \\
\text { size at }\end{array}$} & \multicolumn{5}{|c|}{ Mean number of chicken stock size raised at local states of (S.D.) } & \multirow{2}{*}{ Total } & \multirow{2}{*}{$F$-value } \\
\hline & & Ekiti & Lagos & Ogun & Ondo & Oуо & & \\
\hline \multirow{2}{*}{ Layers } & Initial & $\begin{array}{c}146.60 \\
(183.46)^{\mathrm{aA}}\end{array}$ & $\begin{array}{c}452.29 \\
(573.82)^{\mathrm{cB}}\end{array}$ & $\begin{array}{c}228.44 \\
(500.04)^{\mathrm{bB}}\end{array}$ & $\begin{array}{c}91.92 \\
(139.74)^{\mathrm{aA}}\end{array}$ & $\begin{array}{c}218.66 \\
(445.22)^{\mathrm{bB}}\end{array}$ & $\begin{array}{c}269.62 \\
(418.05)^{A}\end{array}$ & $5.55^{* *}$ \\
\hline & Present & $\begin{array}{c}409.95 \\
(478.67)^{\mathrm{bA}}\end{array}$ & $\begin{array}{c}510.91 \\
(848.10)^{\mathrm{bB}}\end{array}$ & $\begin{array}{c}273.2 \\
(512.14)^{\mathrm{aB}}\end{array}$ & $\begin{array}{c}271.74 \\
(534.61)^{\mathrm{aB}}\end{array}$ & $\begin{array}{c}766.16 \\
(144.74)^{\mathrm{bB}}\end{array}$ & $\begin{array}{c}476.04 \\
(858.78)^{\mathrm{B}}\end{array}$ & $2.81^{*}$ \\
\hline \multirow{2}{*}{ Broilers } & Initial & $\begin{array}{c}185.10 \\
(366.62)^{\mathrm{bA}}\end{array}$ & $\begin{array}{c}168.67 \\
(440.74)^{\mathrm{bA}}\end{array}$ & $\begin{array}{c}48.67 \\
(82.38)^{\mathrm{aA}}\end{array}$ & $\begin{array}{c}81.98 \\
(102.84)^{\mathrm{aA}}\end{array}$ & $\begin{array}{c}37.5 \\
(80.38)^{\mathrm{aA}}\end{array}$ & $\begin{array}{c}107.33 \\
(273.00)^{\mathrm{A}}\end{array}$ & $3.19^{*}$ \\
\hline & Present & $\begin{array}{c}412.34 \\
(705.12)^{\mathrm{cA}}\end{array}$ & $\begin{array}{c}105.43 \\
(140.08)^{\mathrm{bA}}\end{array}$ & $\begin{array}{c}25.44 \\
(60.24)^{\mathrm{aA}}\end{array}$ & $\begin{array}{c}192.0 \\
(340.75)^{\mathrm{bA}}\end{array}$ & $\begin{array}{c}51.02 \\
(111.74)^{\mathrm{aA}}\end{array}$ & $\begin{array}{c}157.23 \\
(381.75)^{\mathrm{B}}\end{array}$ & $8.93^{* *}$ \\
\hline \multirow{2}{*}{ Cockerel } & Initial & $\begin{array}{c}155.85 \\
(320.35)^{\mathrm{bA}}\end{array}$ & $\begin{array}{c}113.50 \\
(460.37)^{\mathrm{bA}}\end{array}$ & $\begin{array}{c}52.8 \\
(92.44)^{\mathrm{aA}}\end{array}$ & $\begin{array}{c}55.20 \\
(108.18)^{\mathrm{aA}}\end{array}$ & $\begin{array}{c}45.5 \\
(92.43)^{\mathrm{aA}}\end{array}$ & $\begin{array}{c}104.1 \\
(269.72)^{\mathrm{A}}\end{array}$ & $4.01^{*}$ \\
\hline & Present & $\begin{array}{c}370.75 \\
(752.11)^{\mathrm{cA}}\end{array}$ & $\begin{array}{c}215.89 \\
(403.49)^{\mathrm{bA}}\end{array}$ & $\begin{array}{c}26.33 \\
(61.81)^{\mathrm{aA}}\end{array}$ & $\begin{array}{c}118.48 \\
(318.64)^{\mathrm{abA}}\end{array}$ & $\begin{array}{c}61.2 \\
(137.28)^{\mathrm{abA}}\end{array}$ & $\begin{array}{c}158.14 \\
(425.91)^{\mathrm{B}}\end{array}$ & $5.34^{*}$ \\
\hline \multicolumn{2}{|c|}{ Total initial stock size } & $\begin{array}{c}487.55 \\
(606.72)^{\mathrm{aA}}\end{array}$ & $\begin{array}{c}855.29 \\
(1311.31)^{\mathrm{bA}}\end{array}$ & $\begin{array}{c}329.91 \\
(546.53)^{\mathrm{aA}}\end{array}$ & $\begin{array}{c}259.1 \\
(229.21)^{\mathrm{aA}}\end{array}$ & $\begin{array}{c}309.66 \\
(455.21)^{\mathrm{aA}}\end{array}$ & $\begin{array}{c}481.05 \\
(740.63)^{\mathrm{A}}\end{array}$ & $5.42^{* *}$ \\
\hline \multicolumn{2}{|c|}{ Total present stock size } & $\begin{array}{c}1195.17 \\
(1555.17)^{\mathrm{cB}}\end{array}$ & $\begin{array}{c}834.33 \\
(1152.85)^{\mathrm{bA}}\end{array}$ & $\begin{array}{c}324.97 \\
(512.75)^{\mathrm{aA}}\end{array}$ & $\begin{array}{c}585.42 \\
(788.66)^{\mathrm{aB}}\end{array}$ & $\begin{array}{c}880.38 \\
(1450.89)^{\mathrm{bB}}\end{array}$ & $\begin{array}{c}791.62 \\
(117.09)^{\mathrm{B}}\end{array}$ & $3.67^{*}$ \\
\hline \multicolumn{2}{|c|}{ Total growth rate $(\%)$} & $\begin{array}{c}241.76 \\
(293.58)^{b}\end{array}$ & $\begin{array}{c}30.08 \\
(125.70)^{\mathrm{a}}\end{array}$ & $\begin{array}{c}25.04 \\
(153.47)^{\mathrm{a}}\end{array}$ & $\begin{array}{c}261.85 \\
(777.56)^{b}\end{array}$ & $\begin{array}{c}216.16 \\
(320.34)^{b}\end{array}$ & $\begin{array}{c}157.64 \\
(424.25)\end{array}$ & $3.81^{*}$ \\
\hline
\end{tabular}

S.D. in parenthesis means standard deviations. The small letters of superscripts were significantly different within rows ( $p<0.05)$. The capital letters of superscripts were significantly different within columns $(p<0.05)$.

${ }^{* *} F$-value with superscripts was significantly different within rows of highest stock size $(p<0.01)$.

${ }^{*} F$-value with superscripts was significantly different within rows of highest stock size or of percent $(p<0.05)$.

tation of ban on importation of frozen food would go a long way in opening up the market for locally produced chicken and further enhance health and disease management and consequently, increased productivity and growth of the enterprise.

\section{ACKNOWLEDGEMENT}

This work was supported by the fund of Korea-Africa Food and Agriculture Cooperation Initiative (KAFACI), Republic of Korea.

\section{REFERENCES}

Akintunde OK, Adeoti AI 2014 Assessment of factors affecting the level of poultry disease management in southwest nigeria. Trend Agri Eco 7:41-56 (Asian Network for Scientific Information).
Aromolaran AK, Ademiluyi IO, Itebu OJ 2009 Challenges of small poultry farms in layer production in Ibadan Oyo State Nigeria. Glob J Sci Fron Res Agri Vet Sci 13(2):Ver. 1.0. Branckaert RDS, Guèye EF 1999 FAO's programme for support to family poultry production. In Dolberg F \& Petersen PH, eds. Poultry as a Tool in Poverty Eradication and Promotion of Gender Equality 244-256 pp. Proceedings workshop, March 22-26.

Diao X, Alpuerto V, Nwafor M 2009 Economy wide impact of avian flu in Nigeria - A dynamic CGE model analysis in: Controlling avian flu and protecting people's livelihoods in Africa and Indonesia. HPAI Research Brief No. 15.

Fadiga M, Jost C, Ihedioha J 2013 Financial costs of disease burden, morbidity and mortality from priority livestock diseases in Nigeria. Disease burden and cost-benefit analysis of targeted interventions. ILRI Research Report 33. Nairobi, Kenya: ILRI. 
Ojo SO 2003 Productivity and technical efficiency of poultry egg production in Nigeria. Intern J Poult Sci 2:459-464.

Okumadewa FI 1999 Livestock industry as a tool for poverty alleviation. Trop J Anim Sci 2:21-30.

Sheahan M, Barrett CB 2014 Understanding the agricultural input landscape in sub-Saharan Africa: Recent plot, house- hold, and community-level evidence. Policy Research Working Paper 7014. World Bank Group Africa Region, Office of the Chief Economist.

Received Sep. 12, 2017, Revised Dec. 3, 2017, Accepted Dec. 6, 2017 
